\title{
Barnacle settlement versus recruitment as indicators of larval delivery. I. Effects of post-settlement mortality and recruit density
}

\author{
Alan L. Shanks* \\ University of Oregon, Oregon Institute of Marine Biology, PO Box 5389, Charleston, Oregon 97420, USA
}

\begin{abstract}
Larval delivery to benthic habitats strongly influences populations and communities. Daily larval settlement and weekly to monthly recruitment have been used to infer larval delivery mechanisms. Daily studies find that delivery varies with wind direction and the spring to neap tidal cycle while recruitment studies find variations related only to upwelling and downwelling. To resolve this dichotomy, the 2 types of observations were replicated simultaneously. 'Safety Walk' settlement plates were divided into quarters, placed in the intertidal zone, and censused daily, weekly, biweekly (i.e. every 2 wk) and monthly. Mortality of settlers on plates was very high; on average $<10 \%$ of cyprids survived to recruit as juveniles. To investigate the high mortality, I sampled ceramic floor tile settlement plates, censused living and dead cyprids daily, and related mortality to weather and surface temperature of settlement plates. In the sun, surface temperature of plates reach 40 to $50^{\circ} \mathrm{C}$ within minutes, resulting in rapid desiccation of cyprids. Surface temperatures of floor tiles and natural rock were significantly lower and mortality on tiles was significantly lower. Settlement rate varied with recruit density; at densities $<10$ ind. $\mathrm{cm}^{-2}$ settlement was enhanced, but above this density settlement was inversely related to recruit density. Due to high cyprid mortality and the effect of recruit density on settlement, barnacle recruitment could not be used to infer mechanisms of larval delivery to the shore.
\end{abstract}

KEY WORDS: Cyprid · Settlement · Recruitment · Safety Walk plates · Upwelling · Downwelling • Upwelling relaxation $\cdot$ Internal tides $\cdot$ Intertidal zone $\cdot$ Balanus glandula

Resale or republication not permitted without written consent of the publisher

\section{INTRODUCTION}

The larvae of many coastal invertebrates and fishes go through a pelagic development phase, at the end of which they must return to the coast to settle and metamorphose. Most larvae are incapable of making this return migration by directly swimming ashore (however, see Leis et al. 1996) and variations in settlement may be related to currents transporting them shoreward. Larval delivery and currents causing shoreward transport may be correlated.

A number of papers have chronicled the daily settlement of barnacles (Hawkins \& Hartnoll 1982, Shanks 1986, Pineda 1991, 1994b, Ladah et al. 2005) and crabs (Shanks 1983, 1986, 1998, 2006, van Montifrans et al. 1990, Mense et al. 1995, Olmi 1995, Johnson \& Shanks
2002, Miller \& Shanks 2004, Queiroga et al. 2006, Roegner et al. 2007), and related variation in settlement rate to variation in hydrography that might cause shoreward transport. Hawkins \& Hartnoll (1982) observed higher daily settlement during periods of onshore winds, suggesting transport of larvae by winddriven onshore surface currents. Settlement of crabs within estuaries was characterized by repeated pulses lasting several days; the pulses varied with the springto-neap tidal cycle, but also with wind direction (van Montifrans et al. 1990, Mense et al. 1995, Olmi 1995, Miller \& Shanks 2004). At a number of open coast study sites, settlement of crabs and barnacles was also pulsed and the pulses were correlated with the springto-neap tidal cycle (Shanks 1983, 1986, 1998, 2006, Pineda 1991, Johnson \& Shanks 2002, Miller \& Shanks 
2004, Roegner et al. 2007). In a few cases, settlement of a species has been measured both on the open coast outside of an estuary and within an estuary (Olmi 1995, Shanks 1998, Miller \& Shanks 2004). On the open coast, settlement varied only with the spring-to-neap tidal cycle, suggesting that shoreward transport was driven by tidal hydrodynamics and not by the wind. Settlement within estuaries varied with both the spring-to-neap tidal cycle and wind direction, suggesting that, as on the open coast, shoreward transport was due to tidal hydrodynamics, but ingress into the estuary was also affected by wind direction. Variation in settlement with the tidal cycle may be due to fortnightly variations in the internal tides, which are capable of causing shoreward larval transport (Shanks 1983, 1987, 1988, Shanks \& Wright 1987, Pineda 1991, 1994a, 1999). Measurements of daily larval settlement have identified a variety of mechanisms of shoreward larval transport, but these studies have provided little evidence that upwelling- or downwelling-favorable winds affect shoreward transport.

A number of studies have examined the recruitment (i.e. survivors after a week to a month) of barnacles and mussels (Connolly \& Roughgarden 1999, Menge et al. 1999, Broitman et al. 2001, 2005, Connolly et al. 2001, Navarrete et al. 2002, 2005 Lagos et al. 2005, Blanchette \& Broitman 2006), particularly recruitment along latitudinal gradients, and have related variations to latitudinal variations in coastal hydrodynamics. These studies have concluded that recruitment varies directly with larval settlement rate, and that settlement varies with coastal upwelling and downwelling. They postulate that larvae are carried away from shore during upwelling and transported shoreward during downwelling or upwelling relaxation (Roughgarden et al. 1987, 1991, Alexander \& Roughgarden 1996). Although these studies were designed to address questions of large-scale spatial differences in recruitment, the results have been interpreted in a temporal context.

The consistent difference between these 2 sets of studies is their sample interval: daily versus weekly to monthly censuses. Possible explanations for the very different conclusions drawn from these studies is that recruitment studies suffer from (1) errors due to postsettlement mortality, (2) density effects on settlement and (3) statistical bias. The present study addresses the first 2 possibilities; (3) is discussed in Shanks (2009).

Ideally, settlement of an intertidal organism should be measured at each low tide; however, this is seldom logistically possible. Daily sampling of settling cyprids is possible (though tedious), and mortality in the first $24 \mathrm{~h}$ after settlement is probably low enough that daily counts represent actual settlement. As the interval between censuses increases, the probability that set- tlers have died or, with mobile animals, moved away from the study site, increases (Roegner 1991, Minchinton \& Scheibling 1993, Pineda et al. 2006). With a long enough sample interval, the number of recruits will have little relation to the number of settlers, and density-dependent effects on recruitment may become important. Because recruitment equals settlement minus mortality and emigration, it is impossible to determine how much settlement, death, or emigration has occurred with just a recruitment measurement (Roegner 1991, Fernandez 1999, Pineda et al. 2006). This suggests that variations in recruitment cannot be used unambiguously to investigate larval settlement or delivery.

Observations of barnacle settlement (daily censuses) and recruitment (weekly to monthly censuses) were made in southern Oregon during summer 2007 using standard techniques. Initially, observations were designed to be 'true replication' (i.e. observations of the same organism in the same habitat using the same sample techniques) (Kelly 2006). The initial experimental design consisted of censuses of settlement and recruitment of Balanus glandula onto deployed 'Safety Walk' settlement plates. To reveal the causes of high cyprid mortality that was observed on the settlement plates during the study, a parallel investigation using an alternative settlement substrate was run.

\section{MATERIALS AND METHODS}

Observations of barnacle settlement were made at a rock (sandstone) outcrop at the southern end of Bas-

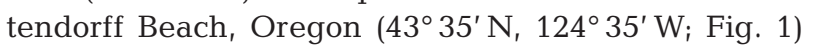
from 21 May to 4 August 2007. The outcrop forms a ridge separating Bastendorff Beach from a small pocket beach, Pirate's Cove. This ridge is $\sim 60 \mathrm{~m}$ long and $\sim 20 \mathrm{~m}$ wide and surrounded by sand. In front of the ridge, towards the sea, is a sandstone platform about $20 \times 30 \mathrm{~m}$ in size (this platform is submerged in Fig. 1). From the sand to about $+2 \mathrm{~m}$ tidal elevation, a dense population of Balanus glandula covers the ridge. Tides are semidiurnal.

To exactly replicate previous research on barnacle settlement and recruitment, a commonly used type of settlement plate, made up of grey Safety Walk ${ }^{\circledR}$ tape on a $10 \times 10 \mathrm{~cm}$ Plexiglas plate (Farrell et al. 1991), was deployed. Holes drilled into the ridge at $+1.75 \mathrm{~m}$ above the zero tide level were fitted with plastic screw anchors, and the plate was held to the rock with a stainless steel screw through the center of the plate. Three replicate plates were deployed within several meters of each other on the east-, west-, and northfacing sides of the ridge within the densely populated barnacle zone (Fig. 1). East-facing plates were fully 

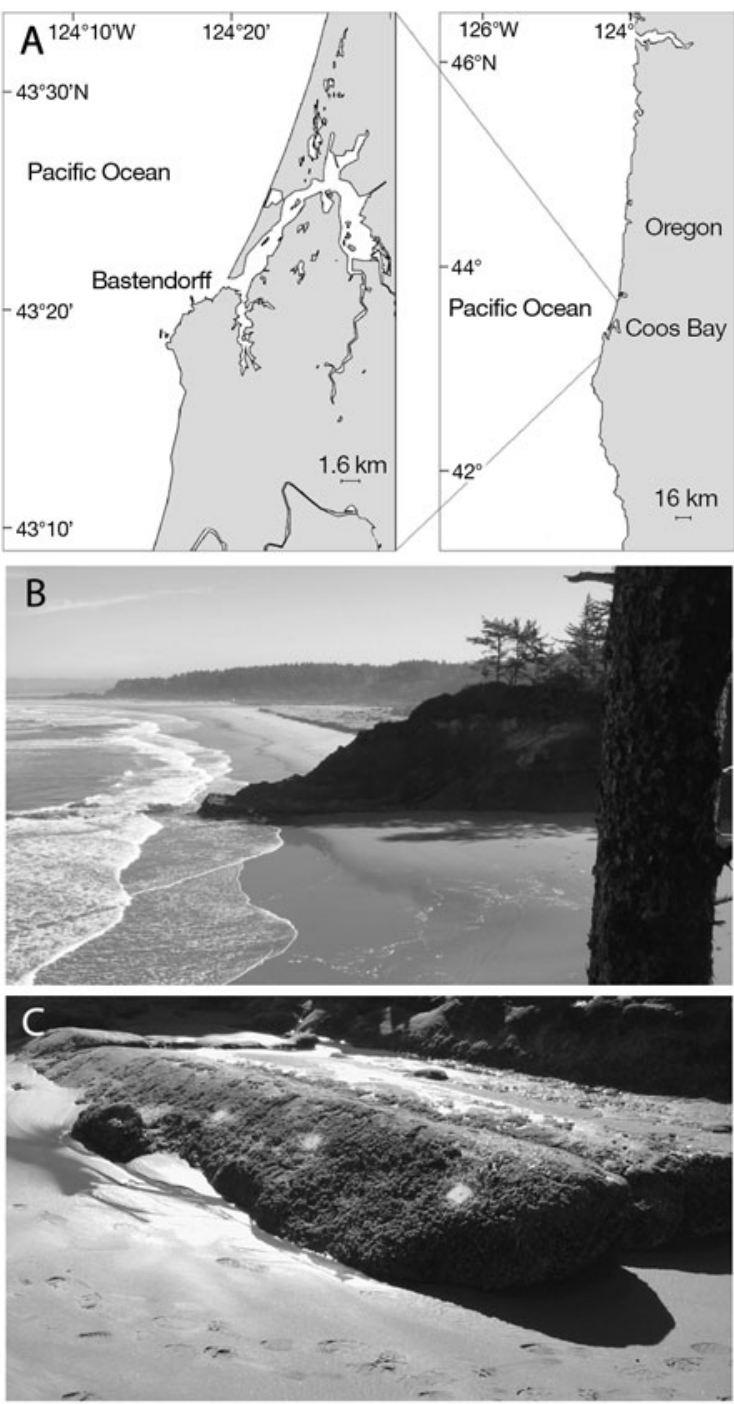

exposed to the sun from early morning onwards, westfacing plates were shaded until early afternoon, and north-facing plates were shaded until late afternoon. Plates were wetted by breaking waves at tides $>+1.5 \mathrm{~m}$ above the zero tide level.

Plates were divided into quarters, and the $25 \mathrm{~cm}^{2}$ subsections were counted daily, weekly, biweekly (i.e. every $2 \mathrm{wk})$, and every $4 \mathrm{wk}$. Censuses were made in the field using a hand lens with 16-fold magnification. Cyprids and recruits (i.e. juveniles) were enumerated daily at tides $\leq+1 \mathrm{~m}$ above the zero tide level. Cyprids present on the plates were considered new settlers while juveniles were considered recruits. The entire $25 \mathrm{~cm}^{2}$ subsection was counted unless counts were high (100s to 1000 s per subsection), in which case only a random subset, generally about $25 \%$, of a section was counted. At the beginning of the study, one plate was returned to the laboratory, inspected with a dissecting microscope and cyprids
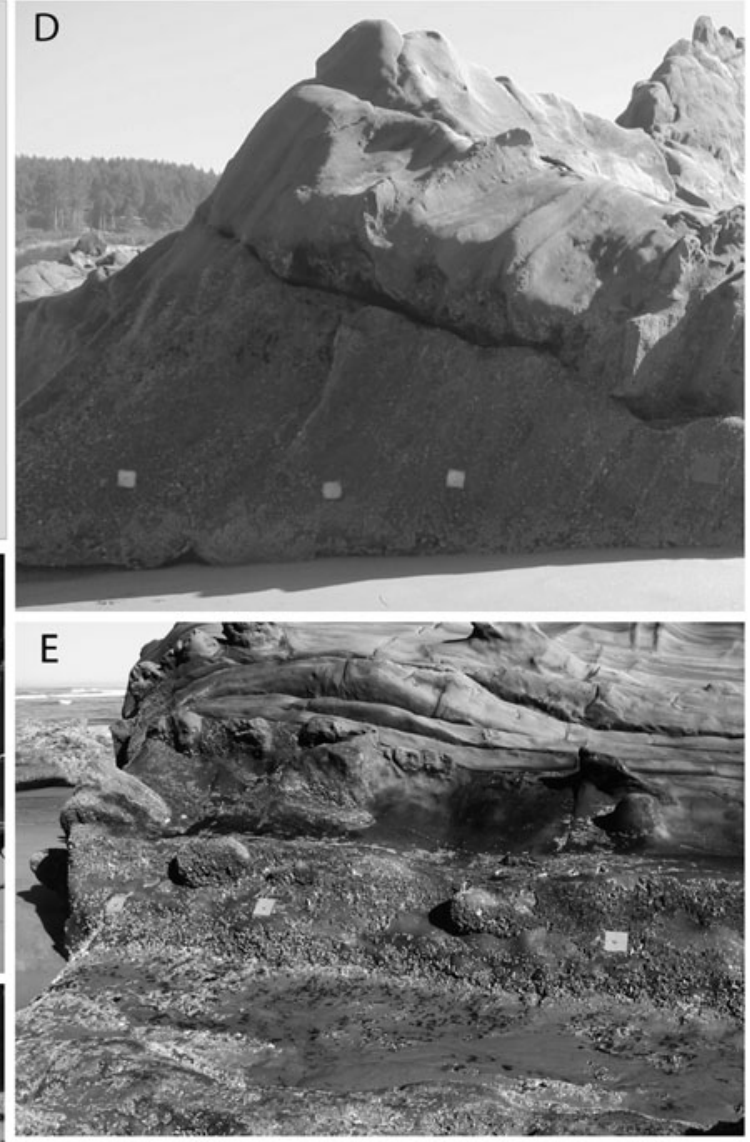

Fig. 1. (A) Bastendorff Beach site. (B) Rock outcrop where sampling occurred. (C) East-, (D) north- and (E) west side of the rock outcrop with deployed settlement plates (gray squares)

were identified to species using Shanks (2001). All barnacles were Balanus glandula, the species composing the surrounding adult population. Chthamalus dalli also settles in the rocky intertidal zone in southern Oregon, but their cyprids are much smaller than those of B. glandula and no small cyprids were observed during counts. After each count, censused quarters of the plate were scrubbed with a toothbrush to remove settlers and recruits $(100 \%$ removed, $\mathrm{n}=14, \mathrm{SD}=0)$.

At the first weekly census, no juveniles were present despite 10 s of cyprids having settled on the daily censused sections of the plates during the week. At the next weekly census, there were still no recruits and many of the cyprids present on the weekly section of the plates appeared to be completely desiccated, suggesting that cyprid survival on the Safety Walk plates was poor. For this reason, a parallel settlement treatment employing ceramic floor tiles was set up. 
The tiles were a mixture of $1 \mathrm{~cm}$ thick, unglazed brown and grey tiles $(15 \times 15 \mathrm{~cm})$ with a grooved bottom surface. On 5 June, random floor tiles were affixed to the rock, with the grooved bottom facing up, at the same tidal elevation and within $30 \mathrm{~cm}$ of each previously deployed settlement plate. Floor tiles were divided into quarters, which were censused following the procedure used for plates. Nearly all cyprids settled into the grooves and, to expedite counting, only individuals in grooves were enumerated. The surface area of the grooves in a quarter of a floor tile was $33.75 \mathrm{~cm}^{2}$. After Week 2, living and dead cyprids were enumerated separately.

At the first 4 wk census, tides were only briefly low enough for counting. Consequently, all plates and tiles were removed and replaced with new plates and tiles, and counts were made in the lab. The new tiles and plates were preconditioned by soaking overnight in a sea table. Because only a limited number of brown floor tiles was available, all of which had been deployed at the beginning of the observations, a new type of floor tile had to be deployed. The new floor tiles, which were used for the remainder of the observations, were $0.7 \mathrm{~cm}$ thick, white, glazed on the top, grooved on the bottom and $11 \times 11 \mathrm{~cm}$ in size. The tile treatement on the north-facing side had to be abandoned after the 4 wk census due to wave damage and vandalism.

Beginning on 10 June, wind speed and wind direction were measured with a handheld anemometer, and air temperature was measured with a laboratory thermometer. Cloud cover was estimated and notes were taken whether plates were exposed to the sun or in the shade. After mid-July, surface temperatures of plates, tiles, and adjacent rock were measured with an infrared thermometer. The accuracy of the infrared thermometer was tested against a laboratory thermistor. Both were used to measure the temperature of a beaker filled with water at a range of temperatures. Measurements of both thermometers were highly correlated $(\mathrm{n}=6, \mathrm{r}=0.9985, \mathrm{p}<0.01)$.

To determine whether recruitment assessed weekly, biweekly, and every 4 wk was different from values based on daily cyprid settlement summed up over the same periods, proportional recruitment was calculated (number of recruits at census / sum of cyprids over that interval). To investigate the effect of location (north-, west-, or east-facing) around the rock on percent recruitment, the data (proportions were arcsine transformed) were analyzed using ANOVA and, when appropriate, Student-Newman-Keuls a posteriori tests were applied to compare results between locations. This analysis was done separately for plate and floor tile data. The proportional recruitment on plates and tiles over the period when both were deployed was compared using ANOVA. Following arcsine transformation, these data were homoscedastic.

Environmental and cyprid mortality data collected during daily counts were sorted by weather condition (e.g. sunny, partly sunny, overcast) and based on whether plates were in the shade. For this analysis, days with low settlement $\left(<10\right.$ ind. $\left.25 \mathrm{~cm}^{-2} \mathrm{~d}^{-1}\right)$ were excluded. After Arcsine transformation, percent mortality on plates and floor tiles during each condition were compared with a paired $t$-test. ANOVA was used to investigate differences in surface temperature between plates, tiles, and rock surface. Following this analysis, Student-Newman-Keuls a posteriori tests were used to compare locations. Confidence levels were altered with a Bonferroni correction for multiple testing.

During Weeks 3 and 4, when settlement and recruitment were high, fewer cyprids were settling on weekly, biweekly, or $4 \mathrm{wk}$ sections of plates than in daily sections, suggesting that recruits might be affecting settlement. To investigate this, cyprids and recruits were censused in daily, weekly, biweekly, and $4 \mathrm{wk}$ sections of plates on 5 dates during these weeks. If there were no density-dependent effects, cyprid density on daily sections should have been similar to that on recruitment sections. To analyze these data, cyprid density in weekly, biweekly, and 4 wk sections was divided by that in the daily section, and the percentage was calculated and regressed against recruit density.

\section{RESULTS}

Daily settlement on east-, north- and west-facing plates was correlated $(\mathrm{r}>0.88, \mathrm{n}=75, \mathrm{p}<0.001$ for each correlation). While the temporal pattern of settlement was very similar, the magnitude of settlement varied significantly by site; settlement on the northfacing plates was highest (settlement on east- and west-facing plates was about 70 and $50 \%$, respectively, of that on the and the north-facing plates), and it was lowest on the east-facing plates (Wilcoxon matched pairs test; east vs. north: $\mathrm{z}=3.16, \mathrm{p}=0.0016$; east vs. west: $\mathrm{z}=4.99, \mathrm{p}<0.00001$; north vs. west: $\mathrm{z}=$ 7.17; $\mathrm{p}<0.000001, \mathrm{n}=75$ in each test). Cyprid settlement on plates and floor tiles varied from 0 to $>1000$ ind. $25 \mathrm{~cm}^{-2} \mathrm{~d}^{-1}$ (data from east-facing side presented for illustration, Fig. 2) and was significantly correlated, indicating that the temporal pattern of settlement on floor tiles and plates was the same. Settlement on the floor tiles was, however, slightly lower than on the plates, with on average $93 \%( \pm 36 \%$, mean \pm SD) of that on plates. Settlement was pulsed, with peaks lasting one to several days during which settlement was 10 to $100 \times$ greater than between pulses (Fig. 2). The 


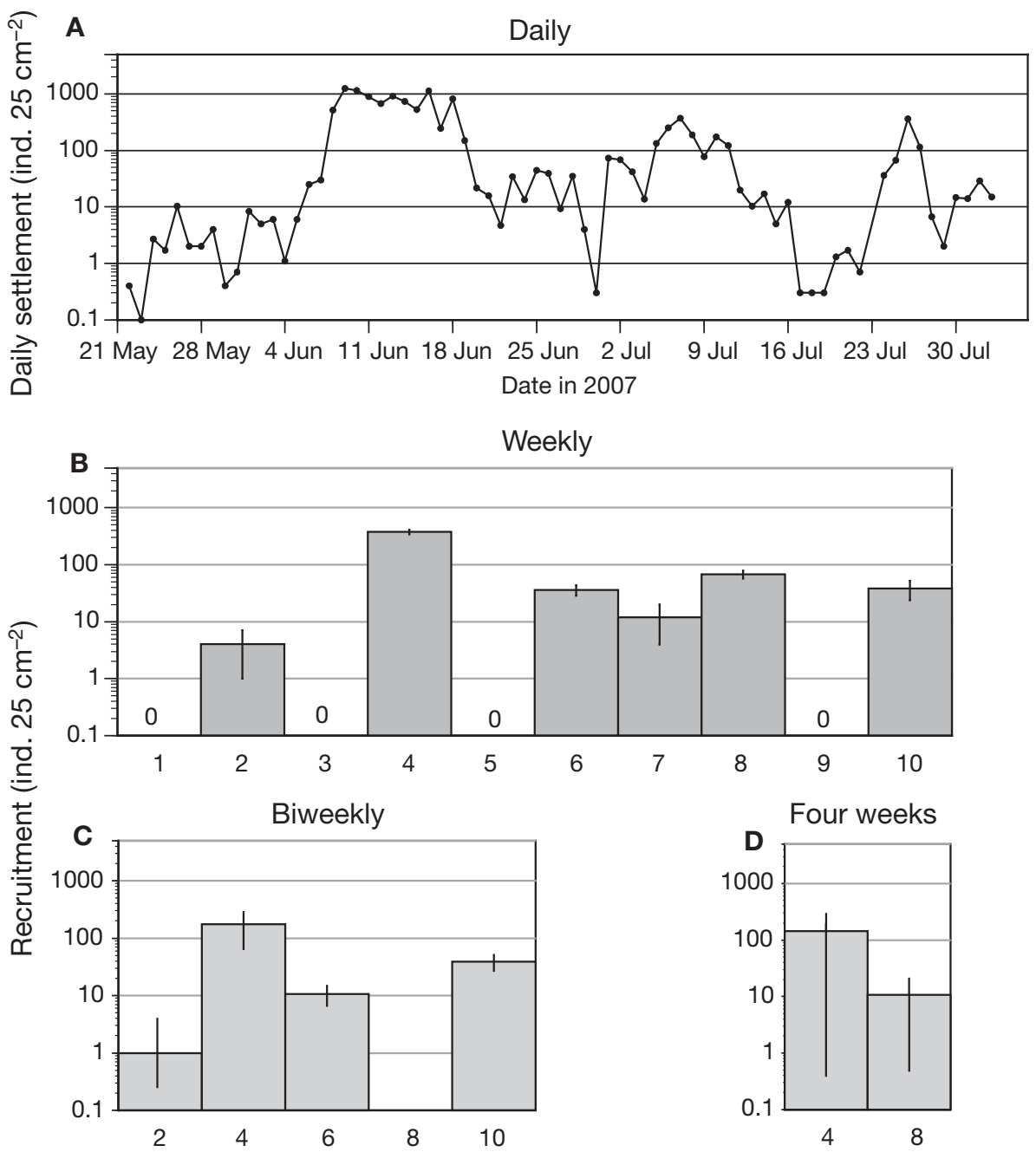

Fig. 2. (A) Daily cyprid settlement compared to recruitment at (B) weekly, (C) biweekly, and (D) 4 wk intervals. Data (mean \pm SE) from east-facing Safety Walk plates

largest pulses occurred between 9 and 16 June, when 1000s of cyprids settled daily.

Weekly recruitment to plates (i.e. juveniles on weekly sections) ranged from 0 to 630 ind. $25 \mathrm{~cm}^{-2}$ on east- and west-facing plates and from 0 to $>1000$ ind. $25 \mathrm{~cm}^{-2}$ on the more shaded north-facing plates, but was much lower than the sum of daily settlement during the week (Fig. 2; Table 1). There were several weeks without any weekly recruitment (Weeks 1, 3, and 5 ; Table 1) and several additional weeks when settlement only occurred on north-facing plates (Week 7 and 9 ; Table 1). Zero recruitment was observed during $2 \mathrm{wk}$ with low settlement (10s of cyprids, Week 1 and 9), another week without any recruitment was during intermediate settlement (sum 100s of cyprids, Week 5), and one week during the peak of cyprid settlement (sum 1000s of cyprids, Week 3). Average weekly recruitment to plates ranged from 0 to $19 \%$ of the sum of daily settlement (overall average $7 \%$, Table 1). Per- cent recruitment on tiles was significantly higher than on plates, ranging from 29 to $69 \%$ (average 47\%) (Table 1). Percent recruitment varied significantly by location. There was no significant difference between east- and west-facing plates, while percent recruitment on the more shaded north-facing plates was significantly different (higher) (Table 1).

Counts for the fourth biweekly count (Week 8) were lost due to human error. Average recruitment on biweekly plates ranged from 4 to 379 ind. $25 \mathrm{~cm}^{-2}$ on east- and west-facing plates, and from 12 to 1984 ind. $25 \mathrm{~cm}^{-2}$ on north-facing plates. Average percent recruitment on biweekly plates ranged from 2 to $20 \%$ (Table 2). No recruitment to any of the 3 west-facing and 2 of the east-facing plates was observed during the second biweekly count (Week 4). No significant difference in percent recruitment by location was detected on the plates during biweekly censuses (Table 2). Recruitment to floor tiles was significantly higher than to 
Table 1. Mean (SE) cyprid settlement on Safety Walk plates and floor tiles censused weekly. The numbers represent cyprids that survived to recruit as juvenile barnacles at the end of the week. A 1-way ANOVA comparing data by location (arcsine transformed data) gave the following results: Safety Walk Plates: $\mathrm{df}=2, \mathrm{MS}$ effect $=69.7, \mathrm{df}=27, \mathrm{MS}$ error $=16.9, F=4.12, \mathrm{p}<0.03$. North-facing plates were significantly different (higher recruitment) from the other plates (Student-Newman-Keuls test, $\mathrm{p}<$ 0.039 ) while east- and west-facing plates were not significantly different. Floor tiles: no significant difference by location (east vs. west). Safety Walk plates vs. floor tiles: $\mathrm{df}=1$, MS effect $=1838, \mathrm{df}=8, \mathrm{MS}$ error $=52, F=34.99, \mathrm{p}<0.00036$. Overall, survival was higher on floor tiles than on Safety Walk plates

\begin{tabular}{|lcccccccccc|}
\hline & Week 1 & Week 2 & Week 3 & Week 4 & Week 5 & Week 6 & Week 7 & Week 8 & Week 9 & Week 10 \\
\hline Safety Walk plates & & & & & & & & & & \\
East & $0(0)$ & $5.3(9.2)$ & $0(0)$ & $2.7(0.6)$ & $0(0)$ & $5.0(1.7)$ & $0.3(0.6)$ & $7.0(4.4)$ & $0(0)$ & $6.5(2.1)$ \\
North & $0(0)$ & $8.0(7.5)$ & $0(0)$ & $10(3.6)$ & $0(0)$ & $18(14)$ & $11(3.5)$ & $19(5.0)$ & $24(18)$ & $22(10)$ \\
West & $0(0)$ & $4.7(8.1)$ & $0(0)$ & $6.7(4.2)$ & $0(0)$ & $7.0(5.2)$ & $0(0)$ & $2.0(2.0)$ & $0(0)$ & $24(28)$ \\
Overall mean & $0(0)$ & $6(7)$ & $0(0)$ & $6(4)$ & $0(0)$ & $10(10)$ & $4(6)$ & $9(8)$ & $8(15)$ & $19(22)$ \\
Floor tiles & & & & & & & & & \\
East & & & $31(11)$ & $74(23)$ & $15(13)$ & $13(5.5)$ & $22(15)$ & & \\
West & & $53(8.5)$ & $62(34)$ & $73(78)$ & $124(64)$ & $72(102)$ & & \\
Overall mean & & $40(15)$ & $69(24)$ & $44(51)$ & $29(69)$ & $53(58)$ & & \\
\hline
\end{tabular}

Table 2. Mean (SE) percentage of cyprids on Safety Walk plates and floor tiles at biweekly and 4 wk census intervals. Numbers represent cyprids that survived to recruit as juveniles at time of census. A 1-way ANOVA (arcsine transformed data) comparing percent recruitment on plates and floor tiles by location found no significant difference. Plates vs. floor tiles: Kruskal-Wallis ANOVA by ranks, $H=17.33, \mathrm{n}=28, \mathrm{p}<0.0001$. Survival was higher on floor tiles than on plates. Biweekly census data for Week 8 were lost. Analyses were not performed with the 4 wk data as the data sets were too small

\begin{tabular}{|c|c|c|c|c|c|c|c|c|}
\hline & \multicolumn{5}{|c|}{ Biweekly census } & & \multicolumn{2}{|c|}{4 wk census } \\
\hline & Week 2 & Week 4 & Week 6 & Week 8 & Week 10 & & Week 4 & Week 8 \\
\hline \multicolumn{9}{|c|}{ Safety Walk plates } \\
\hline East & $2.3(2.3)$ & $2.0(0.6)$ & $2.3(0.7)$ & & $6.1(1.6)$ & East 1 & $1.3(1.5)$ & $0.3(0.6)$ \\
\hline North & $4.4(1.1)$ & $7.2(2.2)$ & $11(8.4)$ & & 47 (33) & North 1 & $11(1.7)$ & 27 (16) \\
\hline West & $0(0)$ & $4.3(1.3)$ & $2.3(0.6)$ & & $6.9(3.9)$ & West 1 & $3.7(3.5)$ & $1.0(0)$ \\
\hline Overall mean & $2.2(1.0)$ & $4.5(1.1)$ & $5.3(2.8)$ & & $20(12)$ & Mean & $5(4.8)$ & $9(16)$ \\
\hline \multicolumn{9}{|l|}{ Floor tiles } \\
\hline East & & $13(1.0)$ & $82(8.7)$ & & & East 1 & & $152(88)$ \\
\hline West & & $31(7.9)$ & 105 (127) & & & West 1 & & 82 (62) \\
\hline Overall mean & & $22(13)$ & $91(67)$ & & & Mean & & $117(79)$ \\
\hline
\end{tabular}

plates, with percent recruitment ranging from 22 to $91 \%$ (Table 2).

Recruitment to plates based on 4 wk censuses ranged from 20 to 272 ind. $25 \mathrm{~cm}^{-2}$ on east- and west-facing plates and from 304 to 1752 ind. $25 \mathrm{~cm}^{-2}$ on north-facing plates (Fig. 2). On average, only 6 to $9 \%$ of cyprid settlers recruited to juveniles (Table 2). Percent recruitment to tiles was higher than to plates (Table 2).

After the first weeks of sampling, it became apparent that cyprids were experiencing high mortality on Safety Walk plates shortly after settlement. Living cyprids are bean-shaped organisms in shades of olive green, their carapace is semitransparent, and they usually appear moist. In contrast, censused cyprids were frequently chalky white and their carapace was opaque; many, while still bean-shaped in outline, were flat, and they were not moist but appeared dry and desiccated. These individuals were clearly not cyprids in the process of metamorphosing into juveniles; rather, they appeared dead and desiccated. The death of cyprids could occur quickly during one low tide. For example, on 17 June, the falling tide exposed the plates at about 04:00 h, sunrise was at 05:38 $\mathrm{h}$ and the east-facing plates were in full sun when censused at 07:20 h. During the first count, $50 \%$ of cyprids appeared to be alive (Fig. 3A) while $1 \mathrm{~h}$ later only $10 \%$ did. Survival rate dropped to $2 \%$ over the next $2 \mathrm{~h}$.

Cyprid mortality was compared to environmental parameters at the time of the counts (Fig. 4). On sunny days, surface temperatures of plates, tiles, and rock were significantly different from each other and from air temperature (Fig. 4). The plates reached temperatures $>40^{\circ} \mathrm{C}$, which was $20^{\circ} \mathrm{C}$ above air temperature. The rock surface was slightly hotter than the floor tiles; both reached temperatures between 21 and $27.7^{\circ} \mathrm{C}$ and were $<10^{\circ} \mathrm{C}$ above air temperature. On partly 
cloudy days, surface temperatures of rock and floor tiles were not significantly different from air temperature, but plates were significantly warmer with surface temperatures from 33 to $39^{\circ} \mathrm{C}\left(>10^{\circ} \mathrm{C}\right.$ above air temperature) (Fig. 4). On overcast days, plates were still significantly hotter than rock, tiles, or air; plate surface temperatures were ranged from 19.7 to $24.7^{\circ} \mathrm{C},\left(<10^{\circ} \mathrm{C}\right.$ above air temperature). In the shade, no significant difference between the surface temperatures and air was observed (Fig. 4).

Under all conditions, daily counts of desiccated cyprids on tiles remained near zero while those on plates varied directly with weather and, hence, surface temperature (Fig. 4). On sunny days, when plate surface temperature was $>40^{\circ} \mathrm{C}$, daily mortality was near $100 \%$. Even on partly cloudy days, when plate surface temperature was 33 to $39^{\circ} \mathrm{C}$, daily mortality was still high near $80 \%$ (Fig. 4C). On overcast days and in the shade, daily mortality on plates dropped to $<10 \%$.

To investigate how quickly Safety Walk plates and floor tiles heat up in the sun, a plate and a brown and white floor tile were soaked in seawater overnight. The wet plates were set in the sun and their surface temperatures were recorded at $\sim 1$ min intervals until the surfaces dried (no visible water) and then reached a stable temperature (Fig. 3B). The white floor tile heated to $25^{\circ} \mathrm{C}$ in $4 \mathrm{~min}$, was dry in $10 \mathrm{~min}$, and the stable temperature was $25^{\circ} \mathrm{C}$. The brown floor tile warmed to $27^{\circ} \mathrm{C}$ in $4 \mathrm{~min}$ and was dry in $8 \mathrm{~min}$, after which surface temperature rose to $36^{\circ} \mathrm{C}$. The Safety Walk plate heated up to $33^{\circ} \mathrm{C}$ in $2 \mathrm{~min}$ and was dry in $10 \mathrm{~min}$, and increased to a stable temperature of $45^{\circ} \mathrm{C}$ in $14 \mathrm{~min}$. All settlement substrates heated up rapidly, dried rapidly, and reached stable temperatures within $15 \mathrm{~min}$.

A plate upon which a large number of cyprids had recently settled was removed from the shady northfacing location and returned to the lab, where it was set in the sun. At intervals of several minutes, the surface temperature was measured and the condition of cyprids monitored with a $16 \times$ magnification hand lens. Plate surface temperature increased rapidly, reaching $40^{\circ} \mathrm{C}$ in $5 \mathrm{~min}$ and $50^{\circ} \mathrm{C}$ in $10 \mathrm{~min}$ (Fig. 3B). Desiccated cyprids first appeared after $7 \mathrm{~min}$, as surface temperature approached $50^{\circ} \mathrm{C}$. The percentage of desiccated cyprids increased rapidly over the next $25 \mathrm{~min}$, and all cyprids appeared desiccated by 32 min (Fig. 3C).

During the large settlement pulse in June, an apparent density-dependent effect was observed. At lower recruit (i.e. juvenile) densities ( $\leq 10$ ind. $\mathrm{cm}^{-2}$ ), the daily abundance of cyprids on recruitment sections of plates was higher than on sections censused daily; average daily cyprid settlement on recruitment sections was $118 \%$ (95 $\pm 10 \%$, mean $\pm \mathrm{CI}, \mathrm{n}=19$ ) of that on the daily censused sections (Fig. 5A). At these low juvenile densities, the presence of some recruits enhanced settlement slightly (gregarious settlement) over that on the daily sections from which juveniles were absent; however, overall cyprid settlement in recruitment sections and sections censused daily was strongly positively correlated with a relationship of nearly 1:1 (Fig. 5B). At juvenile densities $>10$ ind. $\mathrm{cm}^{-2}$, cyprid settlement was inversely related to juvenile density (Fig. 5A). At these higher juvenile densities, daily settlement on the recruitment sections was positively correlated with that on the daily sections
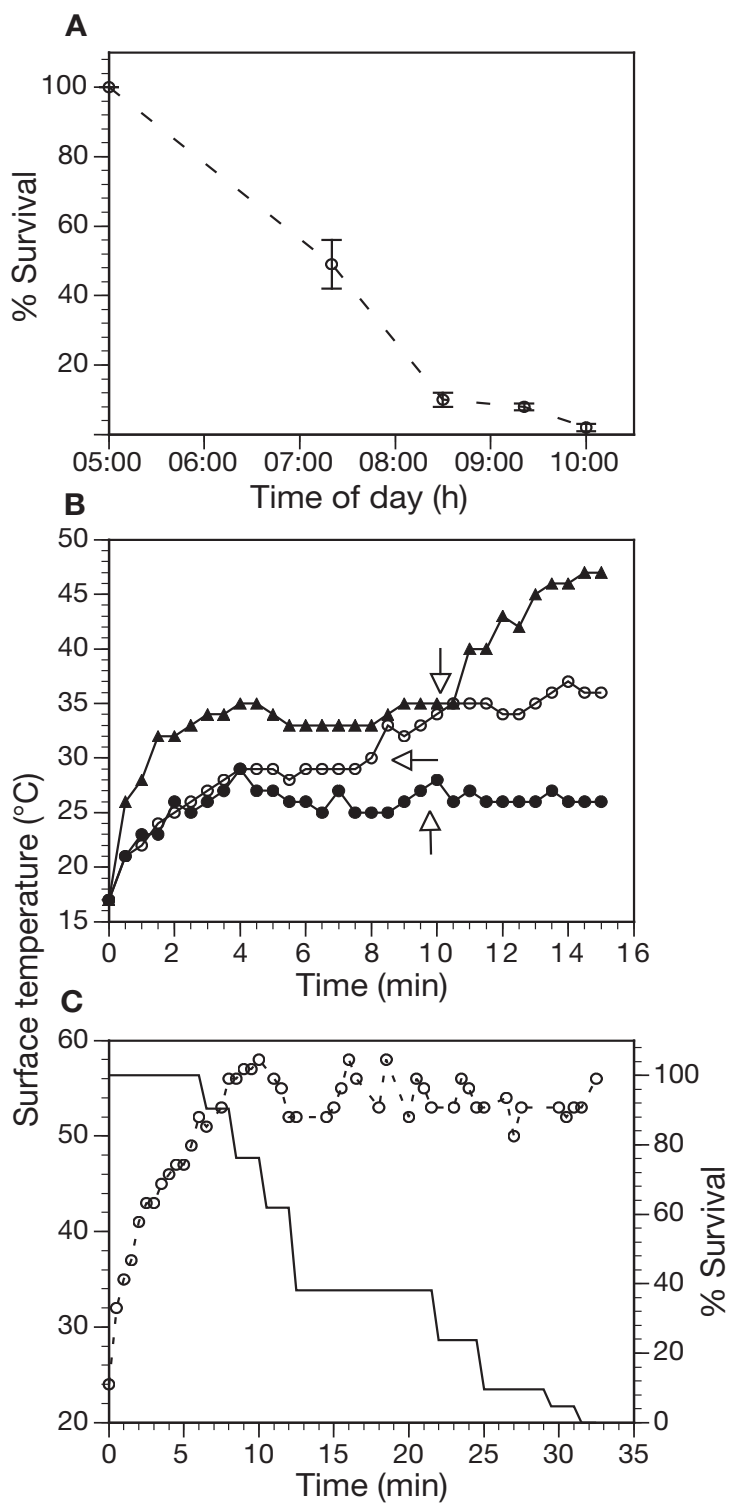

Fig. 3. (A) Percent survival of cyprids (mean \pm SE) on the eastfacing plates during morning low tide on 17 June, 2007, assuming that all cyprids were alive at sunrise $(05: 00 \mathrm{~h})$. (B) Change in surface temperature of a $(\mathbf{\Lambda})$ plate, $(0)$ brown floor tile, and $(\bullet)$ white floor tile. Plates and tiles were soaked in seawater overnight and set in the sun. Arrows indicate the time at which plates and tiles appeared to be dry. (C) Change in surface temperature of a plate $(-Q)$ plotted with percent survival of cyprids on the plate (-) 

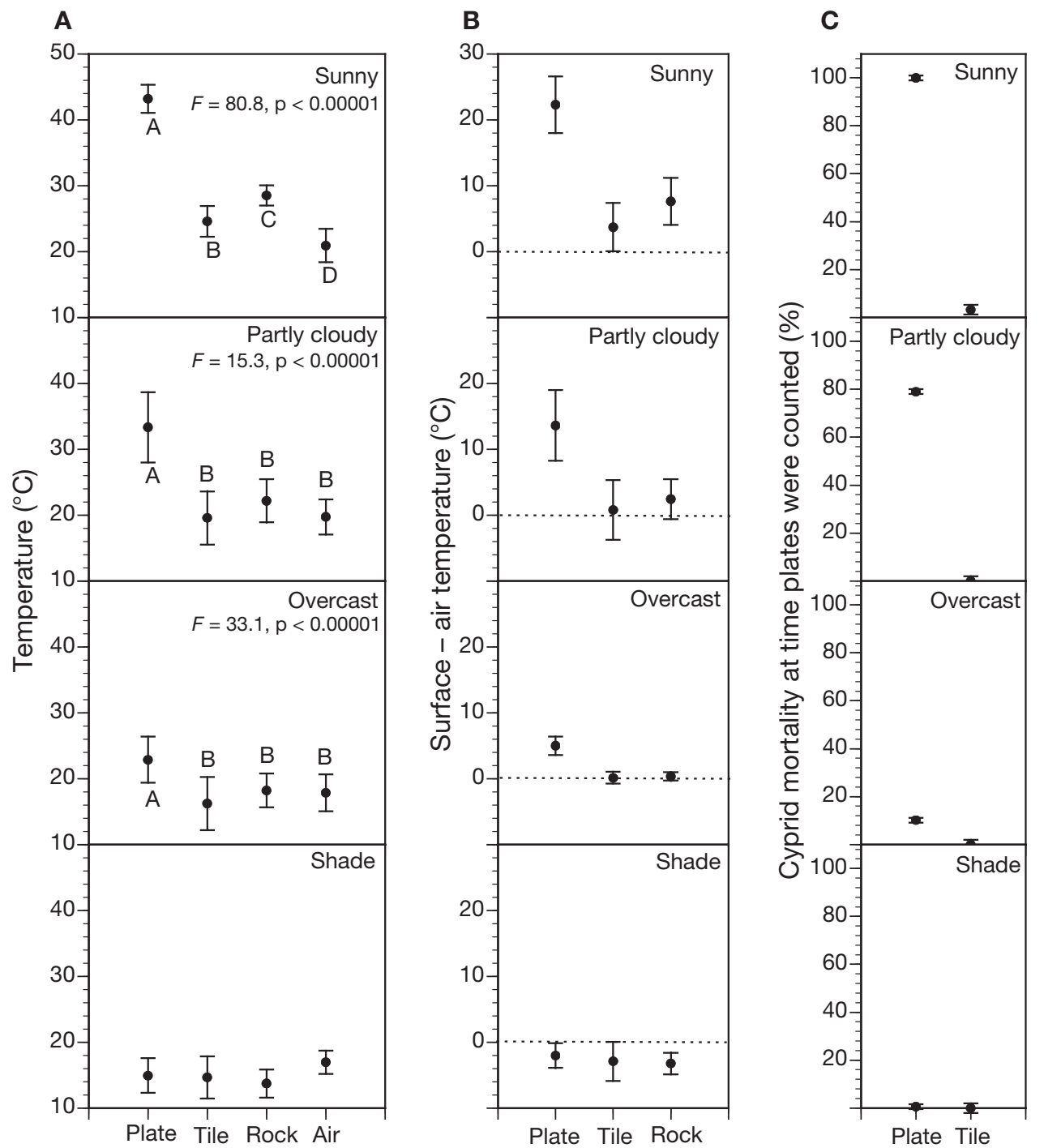

Fig. 4. Effect of weather (sun, overcast, partly cloudy) and shade on temperature and cyprid survival (means $\pm 95 \%$ CI). (A) Air temperature and surface temperatures of plates, tiles, and rock. (B) Difference between air and surface temperatures. (C) Percent cyprid mortality on plates and tiles under different weather and insulation. Surface and air temperature data were analyzed with a 1-way ANOVA. In (A), data points annotated with different letters were significantly different (Student-Newman-Keuls a posteriori test, $\mathrm{p}<0.05)$, while those with the same or no letter did not differ significantly

(Fig. 5B), but settlement was only a fraction of that observed on the daily sections. Daily settlement on the recruitment sections averaged only $62 \%(95 \pm 9 \%, \mathrm{n}=33)$ of that observed on the daily settlement sections of the plates. At higher juvenile densities, juveniles appeared to be inhibiting cyprid settlement.

\section{DISCUSSION}

Daily larval settlement or recruitment assessed at weekly to monthly intervals have been used to investigate how coastal oceanography affects larval supply. These 2 types of studies have arrived at very different conclusions, and the purpose of the present study was to determine why this is so. The differing conclusions may be a consequence of post-settlement mortality in recruitment studies. There should generally be little loss of settlers between settlement and a daily census, but there is ample opportunity for extensive mortality and loss of individuals between settlement and a recruitment census.

Using Safety Walk settlement plates, recruitment was measured weekly, biweekly and every $4 \mathrm{wk}$, and recruitment was compared to the sum of daily larval settlement during these intervals. These data suggested that the recruitment of cyprids to juveniles on plates was exceedingly low: on average, the amount of 

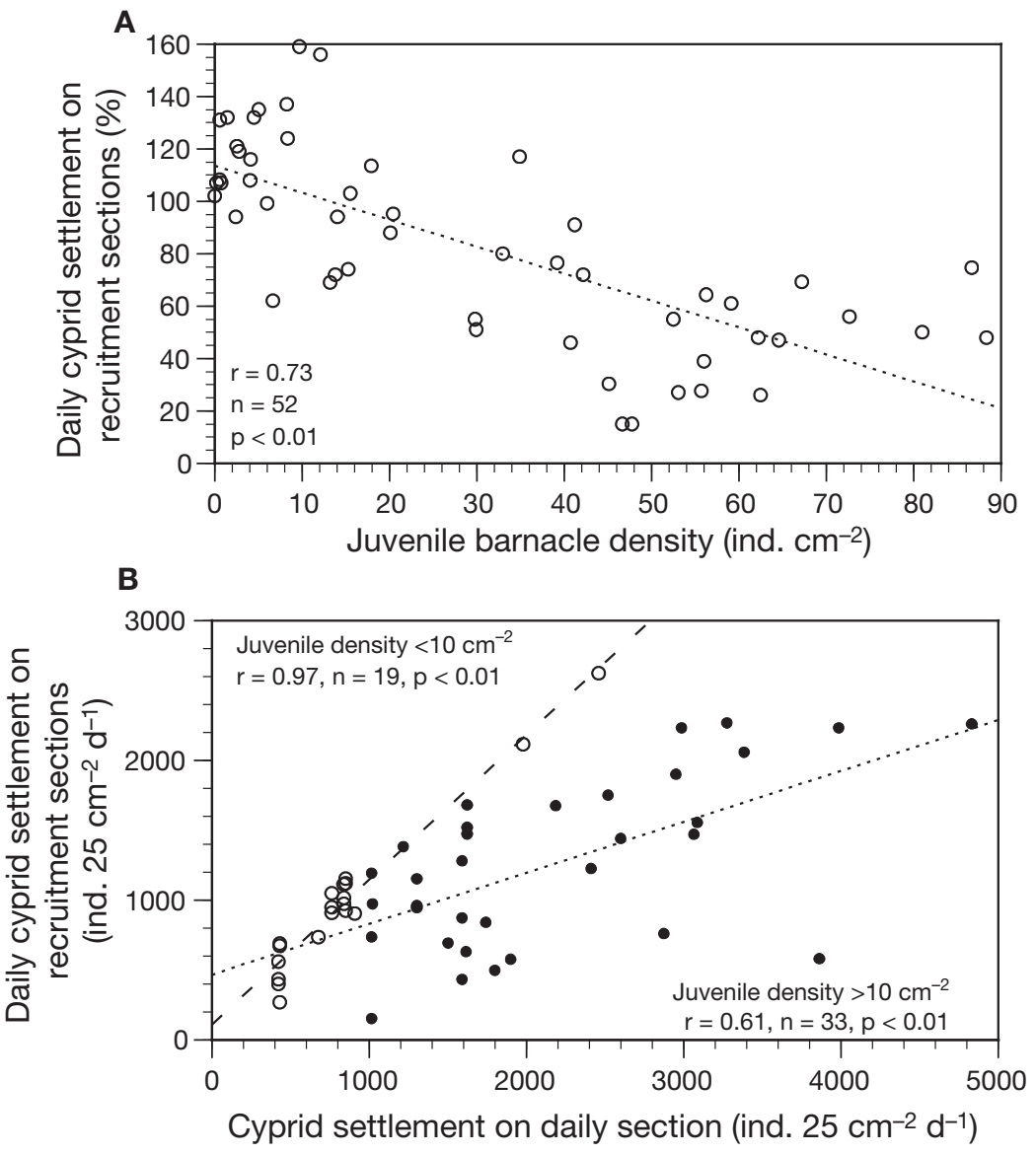

Fig. 5. Effect of recruit density on cyprid settlement in June 2007, when cyprid settlement was very high. (A) Density of juveniles on recruitment sections of plates, plotted against daily cyprid counts in the 3 recruitment sections of the 3 plates divided by cyprids in the daily settlement section. At recruit density $\leq 10$ ind $\mathrm{cm}^{-2}$, settlement in recruit sections of plates was higher than in daily sections; settlement was enhanced by the presence of recruits. At recruit densities $>10$ ind $\mathrm{cm}^{-2}$, settlement decreased with increasing juvenile density. (B) Daily cyprid settlement in the sections of the plate counted daily plotted against calculated daily cyprid settlement in the recruitment sections censused weekly, biweekly and every $4 \mathrm{wk}$. This relationship is plotted for periods when juvenile density on the recruitment plate sections was $(0) \leq 10$ ind. $\mathrm{cm}^{-2}$ and $(\bullet)>10$ ind. $\mathrm{cm}^{-2}$

juveniles on the sections of the plates censused at weekly, biweekly, or $4 \mathrm{wk}$ intervals was $<7 \%$ the amount of cyprids on the portion of the plates counted daily (Tables 1 \& 2). In 3 out of 10 weekly recruitment censuses, no juveniles were found on the 9 replicate plates, while 10 s to 100 s of cyprids had, during the same time frame, settled on the section of the plates that were censused daily (Table 1). One possible explanation for this could be that substances released during the daily removal of cyprids from these sections made them more attractive to new settlers. In fact, pretreating settlement plates with homogenized barnacles is one way in which researchers enhance settlement. Conversely, higher cyprid settlement to daily sections compared to recruitment sections may indicate that survival from cyprid to juvenile was low on the recruitment sections. The data on recruit density compared to settlement presented in (Fig. 5) can be used to address this question. When juvenile densities on the weekly sections of the plates were above 10 ind. $\mathrm{cm}^{-2}$, daily cyprid settlement to these sections appears to have been inhibited. When the number of recruits was below this density, however, daily settlement of cyprids on the daily and weekly sections of the plates were significantly correlated and similar in magnitude (Fig. 5). These results suggest that the removal of cyprids by brushing did not enhance their settlement on the daily sections of the plates.

Another possibility is that, between my daily and weekly counts, predation removed significant numbers of cyprids and new juveniles, leading to low recruitment. Limpets and nemertean worms Emplectonema gracile that prey on barnacles were abundant at the study site; however, E. gracile were only observed on the shady north side of the rock and this was also the only location where limpets were abundant. Hence, predation should have been highest on the north side; however, recruitment of cyprids to juveniles was highest at this location, suggesting that predation may have played only a minor role in reducing the number of recruits.

While daily settlement on the tiles and plates was similar, survival to recruitment was much higher on the tiles: on weekly tiles, an average of $47 \%$ of the cyprids recruited while only about $6 \%$ on plates did (Table 1), suggesting that mortality on plates was excessively high. The investigation into cyprid mortality on plates indicated that heat was likely the cause. I found only 1 study on the tolerance of cyprids to high temperatures. This study found that cyprids passing through the cooling system of a power plant were killed by 10 to $15 \mathrm{~min}$ of exposure to $45^{\circ} \mathrm{C}$ water (Thiyagarajan et al. 2000); this is similar to my observations of cyprid survival on plates in the sun. L. Ackley (pers. comm.) exposed, under dry conditions, Balanus spp. cyprids to temperatures from 17 to $40^{\circ} \mathrm{C}$ on a heat block for $40 \mathrm{~min}$. Only $10 \%$ of the cyprids survived at $30^{\circ} \mathrm{C}$ and none did at $40^{\circ} \mathrm{C}$. 
Safety Walk plates are a highly attractive settlement surface for cyprids, but, because plates rapidly heat up to lethal temperatures when exposed to the sun, they are a poor choice for a recruitment substrate. This is a surprising and disconcerting discovery. Safety Walk plates were first used by Farrell et al. (1991) to investigate cyprid settlement and have since been used extensively to investigate barnacle recruitment. They have been used most commonly in studies on the West Coast of North America (Connolly \& Roughgarden 1999, Menge 2000, Connolly et al. 2001, Broitman et al. 2005, Blanchette \& Broitman 2006), but also in Chile (Broitman et al. 2001, Navarrete et al. 2002, 2005, Lagos et al. 2005) and New Zealand (Menge et al. 1999, 2003). This body of work has strongly influenced our current thinking about the relationship between coastal oceanography, particularly upwelling and downwelling, and delivery of larvae to the shore. Solar heating of Safety Walk plates clearly calls into question the results and conclusions from recruitment studies that have used these plates.

Studies have interpreted variation in recruitment of barnacles, mussels and crabs as due to oceanographic events altering larval supply (Wing et al. 1995a,b, Alexander \& Roughgarden 1996, Shkedy \& Roughgarden 1997, Connolly et al. 2001). The assumption is that recruitment varies directly with settlement, but this is only true if settlement and mortality are densityindependent (Connell 1985). In the present study, when settlement peaked in June, cyprid settlement on weekly to 4 wk sections of Safety Walk plates varied inversely with recruit density (Fig. 5A). At lower juvenile densities, daily cyprid settlement on recruitment sections of plates was higher than on daily sections, suggesting that cyprids settled gregariously with recruits. At higher densities, settlement on recruitment sections varied inversely with recruit density; either recruits prevented settlement or cyprids were avoiding areas of high recruit density. Gregarious settlement of barnacles and inhibition of settlement at higher densities is a recognized feature of barnacle ecology (Barnett \& Crisp 1979, Barnett et al. 1979) and was clearly evident in the data from the present study.

Mortality between settlement and recruitment on plates appears to be density-independent and, hence, recruitment should vary directly with settlement. This relationship will only hold if density-independent mortality is not so extreme as to remove most or all settlers; however, this is exactly what was observed on the plates. There were several weeks during which 100 s to 1000 s of cyprids settled on plates, but none survived to recruit (Fig. 2). This frequent, catastrophic, density-independent mortality compromises the assumption of a relationship between recruitment and settlement.
The purpose of the present study was to determine why different studies measuring cyprid settlement daily or barnacle recruitment at weekly or longer intervals have arrived at very different conclusions as to the mechanism(s) causing delivery of cyprids to the shore. By measuring settlement and recruitment, using standard techniques, at the same place and over the same time frame, the 2 types of studies were exactly replicated, allowing for a direct comparison of the results. A possible explanation for the very different conclusions drawn from these studies is that recruitment studies suffer from errors due to post-settlement mortality and/or density effects on settlement and recruitment. I conclude that (1) Safety Walk settlement plates work well for daily settlement, but, due to excessive and rapid solar heating causing the death of attached cyprids, their use in recruitment studies is problematic. (2) In the sun, floor tile settlement plates did not heat up as much and recruitment was much higher than on Safety Walk plates. (3) During periods of high settlement, settlement and recruitment were density-dependent. (4) Frequent, catastrophic post-settlement mortality on Safety Walk plates and the effect of recruit density on settlement calls into question the relationship between recruitment and settlement.

Acknowledgements. Research funded by National Science Foundation Small Grant for Exploratory Research OCE 0715425. L. Shanks, G. Shanks, S. Schroeder, J. Marin Jarrin, A. Leferriere, E. Cooper, A. Pollard, and K. Bennett helped with counting cyprids. J. Hodder, J. Miller and C. Roegner provided comments on drafts of the paper.

\section{LITERATURE CITED}

Alexander SE, Roughgarden J (1996) Larval transport and population dynamics of intertidal barnacles: a coupled benthic/oceanic model. Ecol Monogr 66:259-275

Barnett BE, Crisp DJ (1979) Laboratory studies of gregarious settlement in Balanus balanoides and Elminius modestus in relation to competition between thee species. J Mar Biol Assoc UK 59:581-590

Barnett BE, Edwards SC, Crisp DJ (1979) A field study of settlement behaviour in Balanus balanoides and Elminiu modestus (Cirripedia: Crustacea) in relation to competition between them. J Mar Biol Assoc UK 59:575-580

> Blanchette C, Broitman B (2006) Intertidal community structure and oceanographic patterns around Santa Cruz Island, CA, USA. Mar Biol 149:689-701

Broitman BR, Navarrete SA, Smith F, Gaines SD (2001) Geographic variation in southeastern Pacific intertidal communities. Mar Ecol Prog Ser 224:21-34

Broitman BR, Blanchette CA, Gaines SD (2005) Recruitment of intertidal invertebrates and oceanographic variability at Santa Cruz Island, California. Limnol Oceanogr 50: 1473-1479

Connell JH (1985) The consequences of variation in initial settlement vs. post-settlement mortality in rocky intertidal communities. J Exp Mar Biol Ecol 93:11-45 
Connolly SR, Roughgarden J (1999) Increased recruitment of northeastern Pacific barnacles during the 1997 El Nino. Limnol Oceanogr 44:466-469

Connolly SR, Menge BA, Roughgarden J (2001) A latitudinal gradient in recruitment of intertidal invertebrates in the northeast Pacific Ocean. Ecology 82:1799-1813

Farrell TM, Bracher D, Roughgarden J (1991) Cross-shelf transport causes recruitment to intertidal populations in central California. Limnol Oceanogr 36:279-288

Fernandez M (1999) Cannibalism in Dungeness crab Cancer magister: effects of predatory-prey size ratio, density and habitat type. Mar Ecol Prog Ser 182:221-230

Hawkins SJ, Hartnoll RG (1982) Settlement patterns of Semibalanus balanoides (L.) in the Isle of Man (1977-1981). J Exp Mar Biol Ecol 62:271-283

Johnson J, Shanks AL (2002) Time series of the abundance of the post-larvae of the crabs Cancer magister and Cancer spp. on the southern Oregon coast and their cross-shelf transport. Estuaries 25:1138-1142

Kelly CD (2006) Replicating empirical research in behavioral ecology: how and why it should be done but rarely ever is. Q Rev Biol 81:221-236

Ladah LB, Tapia FJ, Pineda J, López M (2005) Spatially heterogeneous, synchronous settlement of Chthamalus spp. larvae in northern Baja California. Mar Ecol Prog Ser 302: $177-185$

Lagos N, Navarrete SA, Véliz F, Masuero A, Castilla JC (2005) Meso-scale spatial variation in settlement and recruitment of intertidal barnacles along the coast of central Chile. Mar Ecol Prog Ser 290:165-178

Leis JM, Sweatman PA, Reader SE (1996) What pelagic stages of coral reef fishes are doing in blue water: daytime field observation of larval behavioral capabilities. Mar Freshw Res 47:401-412

Menge BA (2000) Top-down and bottom-up community regulation in marine rocky intertidal habitats. J Exp Mar Biol Ecol 250:257-289

Menge BA, Daley BA, Lubchenco J, Sanford E and others (1999) Top-down and bottom-up regulation of New Zealand rocky intertidal communties. Ecol Monogr 69: 297-330

Menge BA, Lubchenco J, Bracken M, Chan F and others (2003) Coastal oceanography sets the pace of rocky intertidal community dynamics. Proc Natl Acad Sci USA 100: 12229-12234

Mense DJ, Posey MH, West T, Kincheloe T (1995) Settlement of brachyuran postlarvae along the North Carolina coast. Bull Mar Sci 57:793-806

Miller JA, Shanks AL (2004) Ocean-estuary coupling in the Oregon upwelling region: abundance and transport of juvenile fish and of crab megalopae. Mar Ecol Prog Ser 271:267-279

Minchinton TE, Scheibling RE (1993) Variations in sampling procedure and frequency affect estimates of recruitment of barnacles. Mar Ecol Prog Ser 99:83-88

Navarrete SA, Broitman B, Wieters EA, Finke GR, Venegas RM, Sotomayor A (2002) Recruitment of intertidal invertebrates in the southeast Pacific: interannual variability and the 1997-1998 El Nino. Limnol Oceanogr 47:791-802

Navarrete SA, Wieters EA, Broitman BR, Castilla JC (2005) Scales of benthic-pelagic coupling and the intensity of species interactions: from recruitment limitation to topdown control. Proc Natl Acad Sci USA 102:18046-18051

Olmi EJI (1995) Ingress of blue crab megalopae in the York River, Virginia, 1987-1989. Bull Mar Sci 57:753-780

Pineda J (1991) Predictable upwelling and the shoreward transport of planktonic larvae by internal tidal bores.
Science 253:548-551

Pineda J (1994a) Internal tidal bores in the nearshore: warmwater fronts, seaward gravity currents and the onshore transport of neustonic larvae. J Mar Res 52:427-458

> Pineda J (1994b) Spatial and temporal patterns in barnacle settlement rate along a southern California rocky shore. Mar Ecol Prog Ser 107:125-138

Pineda J (1999) Circulation and larval distribution in internal tidal bore warm fronts. Limnol Oceanogr 44:1400-1414

Pineda J, Starczak V, Stueckle TA (2006) Timing of successful settlement: demonstration of a recruitment window in the barnacle Semibalanus balanoides. Mar Ecol Prog Ser 320: 233-237

> Queiroga H, Almeida MJ, Alpuim T, Flores AV and others (2006) Tide and wind control of megalopal supply to estuarine crab populations on the Portuguese west coast. Mar Ecol Prog Ser 307:21-36

> Roegner G (1991) Temporal analysis of the relationship between settlers and early recruits of the oysters Crassostrea virginica (Gmelin). J Exp Mar Biol Ecol 151:57-69

$>$ Roegner GC, Armstrong DA, Shanks AL (2007) Wind and tidal influences on larval crab recruitment to an Oregon estuary. Mar Ecol Prog Ser 351:177-188

Roughgarden J, Gaines SD, Pascala SW (1987) Supply-side ecology: the role of physical transport processes. In: Giller P, Gee J (eds) Organization of communities: past and present. Blackwell Scientific, London

Roughgarden J, Pennington JT, Stoner D, Alexander S, Miller K (1991) Collisions of upwelling fronts with the intertidal zone: The cause of recruitment pulses in barnacle populations of central California. Acta Oecol 12:35-51

Shanks AL (1983) Surface slicks associated with tidally forced internal waves may transport pelagic larvae of benthic invertebrates and fishes shoreward. Mar Ecol Prog Ser 13: 311-315

Shanks AL (1986) Tidal periodicity in the daily settlement of intertidal barnacle larvae and an hypothesized mechanism for the cross-shelf transport of cyprids. Biol Bull (Woods Hole) 170:429-440

Shanks AL (1987) The onshore transport of an oil spill by internal waves. Science 235:1198-1200

Shanks AL (1988) Further support for the hypothesis that internal waves can transport larvae of invertebrates and fish onshore. Fish Bull (Wash DC) 86:703-714

> Shanks AL (1998) Abundance of post-larval Callinectes sapidus, Penaeus spp., Uca spp., and Labinia spp. collected at an outer coastal site and their cross-shelf transport. Mar Ecol Prog Ser 168:57-69

Shanks AL (2001) An identification guide to the larval marine invertebrates of the Pacific Northwest. Oregon State University Press, Corvallis, OR

> Shanks AL (2006) Mechanisms of cross-shelf transport of crab megalopae inferred from a time series of daily abundance. Mar Biol 148:1383-1398

> Shanks AL (2009) Barnacle settlement versus recruitment as indicators of larval delivery. II. Time-series analysis and hypothesized delivery mechanisms. Mar Ecol Prog Ser 385: 217-226

> Shanks AL, Wright WG (1987) Internal-wave-mediated shoreward transport of cyprids, megalopae, and gammarids and correlated longshore differences in the settling rate of intertidal barnacles. J Exp Mar Biol Ecol 114:1-13

> Shkedy Y, Roughgarden J (1997) Barnacle recruitment and population dynamics predicted from coastal upwelling. Oikos 80:487-498

> Thiyagarajan V, Nancharaiah YV, Venugopalan VP, Nair KVK, Subramoniam T (2000) Relative tolerance of cirri- 
pede larval stages to acute thermal shock: a laboratory study. J Therm Biol 25:451-457

van Montifrans J, Peery CA, Orth RJ (1990) Daily, monthly and annual settlement patterns by Callinectes sapidus and Neopanope sayi megalopae on artificial collectors deployed in the York River, Virginia. Bull Mar Sci 46: $214-229$

Editorial responsibility: Hans Heinrich Janssen, Oldendorf/Luhe, Germany
Wing SR, Botsford LW, Largier JL, Morgan LE (1995a) Spatial structure of relaxation events and crab settlement in the northern California upwelling system. Mar Ecol Prog Ser 128:199-211

Wing SR, Largier JL, Botsford LW, Quinn JF (1995b) Settlement and transport of benthic invertebrates in an intermittent upwelling region. Limnol Oceanogr 40:316-329

Submitted: July 4, 2008; Accepted: May 7, 2009

Proofs received from author(s): June 9, 2009 